Souza, L.H.; Oliveira, M.V.N. Zoneamento turístico em áreas naturais protegidas: um diálogo entre conservação, oferta de atrativos e perfil da demanda ecoturística. Anais do VII Congresso Nacional de Ecoturismo e do III Encontro Interdisciplinar de Ecoturismo em Unidades de Conservação. Revista Brasileira de Ecoturismo, São Paulo, v.4, n.4, 2011, p.494.

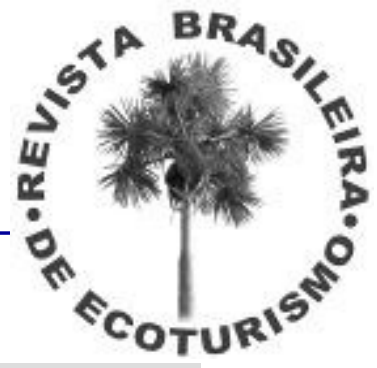

\title{
ZONEAMENTO TURÍSTICO EM ÁREAS NATURAIS PROTEGIDAS: UM DIÁLOGO ENTRE CONSERVAÇÃO, OFERTA DE ATRATIVOS E PERFIL DA DEMANDA ECOTURÍSTICA
}

\author{
Luis Henrique Souza*, Marcus Vinícius Noronha Oliveira** \\ *Universidade Federal de Pernambuco, ${ }^{*}$ Universidade Federal de Sergipe \\ E-mails: luis_rce@yahoo.com.br,mv_bioufs@hotmail.com
}

As Áreas Naturais Protegidas (ANP's) apresentam vocações singulares para a prática do ecoturismo, suscitando a dialética entre as funções intrínseca e utilitária destes territórios e revelando preocupações com a conservação do acervo biótico e abiótico e com a sensibilidade do tecido social local. Em função dos impactos negativos provocados pelo turismo e a necessidade de estabelecer instrumentos que viabilizem na prática as premissas da sustentabilidade, advogase uma maior relevância quanto à aplicação de modelos de gestão do turismo em ANP's. Neste sentido, o presente artigo realiza uma abordagem que aproxima a oferta de atrativos das ANP's com diferentes perfis da demanda ecoturística, com o objetivo de apresentar uma proposta de Zoneamento turístico, tendo como estudo de caso o Parque Nacional da Serra de Itabaiana (PARNASI) no estado de Sergipe. Para tanto, utilizou-se uma metodologia de estudo descritivo, mediante a coleta de dados por entrevista e observação direta, além de pesquisa documental. A literatura apresenta diversas tipologias de perfis de ecoturistas e neste trabalho serão detalhados os estudos de Fernie que classifica a demanda ecoturística em Eco-Especialistas, EcoIntermediários e Eco-Generalistas. Para estabelecer a correlação entre as atividades preferenciais destes perfis e Zoneamento turístico, foi utilizado o modelo ROS (Recreational Opportunity Spectrum). Os resultados mostram o contributo potencial das estratégias de Zoneamento turístico para a conservação e melhoria da experiência turística, através da conciliação entre o perfil do ecoturista e a oferta de atrativos naturais das ANP's. Assim, este estudo revelou a existência de infraestruturas e facilidades, a exemplo do acesso principal ao PARNASI; da trilha para a cachoeira do Poço das Moças e do Centro Administrativo, os quais atendem às necessidades do perfil "Eco-generalista" e configuram o Zoneamento "Recreativo Intensivo" do modelo ROS. De modo semelhante, o PARNASI apresenta um conjunto de trilhas de longo curso ou de difícil acesso que atendem às motivações do perfil "Eco-Especialista", destacando-se a zona da trilha do Caldeirão, que conduz o turista às cachoeiras do Caldeirão, da Árvore e do Cipó e prossegue até o 'Topo da Serra". Neste percurso, o turista conhece a flora diversificada do PARNASI, sua avifauna e formações geológicas singulares, ou seja, zonas com ecossistemas de valores inestimáveis próprias do Zoneamento Natural Intensivo do ROS. As Trilhas da Via Sacra e do Véu de Noivas, por sua vez, atendem ao perfil "Eco-intermediário" em função do baixo grau de dificuldade para percorrê-las, representando uma zona do tipo Natural Intensivo. Conclui-se que a gestão do ecoturismo, apoiado em estratégias de Zoneamento turístico, representa um caminho para o alcance dos objetivos da sustentabilidade do turismo em ANP's, mediante a segmentação e aproximação do potencial da oferta turística destes territórios com as motivações dos diferentes perfis de demanda ecoturística, devendo, portanto, ser estabelecida uma gestão dos fluxos turísticos de modo a direcionar cada perfil da demanda para as Zonas turísticas da ANP que mais se adéquam a cada perfil.

Palavras-chave: Áreas Naturais Protegidas; Zoneamento Turístico; Demanda Ecoturística. 